\title{
Uncertainties of soil parameterisation in process-based simulation of distributed flood control measures
}

\author{
W. Rieger, F. Winter, and M. Disse \\ Institute of Hydro Sciences, Universität der Bundeswehr München, Munich, Germany \\ Received: 22 January 2010 - Revised: 4 June 2010 - Accepted: 9 June 2010 - Published: 8 October 2010
}

\begin{abstract}
Distributed flood control measures such as landuse changes or differing soil tillage practices which affect the runoff generation process, are hard to simulate physically based due to a high degree of uncertainty with regard to soil parameterisation. In this study the physically based rainfall runoff model WaSiM-ETH (Version 8.4.2) was used with a multi-layered vegetation and soil parameterisation. The modelling area was the meso-scaled and rurally characterised Windach catchment. In addition, soil measurement datasets were compared to demonstrate the uncertainties in soil parameterisation of physically based models. The datasets were gained from the hillslope scale at the Scheyern research farm with similar soil conditions to the Windach catchment. While parameterising and calibrating the model, seven different pedotransfer functions were used with strong influence on the simulated hydrographs. The differing bulk densities of soils depending on land-use and soil tillage must be taken into consideration due to their high impact on modelling results, and they also offer a comprehensive way to model distributed flood control measures. These measures have noticeable effects on flood events under $\mathrm{HQ}_{10}$, especially if the land-use type which is affected by the distributed flood control measure is the dominating land-use form in the catchment area. To account for the variability of soils in the investigation area of Scheyern, different approaches were applied to estimate soil hydraulic properties and saturated hydraulic conductivity, and were compared to field measurements.
\end{abstract}

\section{Introduction}

Aside from technical protection and forecasting, modern flood prevention strategies include distributed flood control measures (DFCM) (StMLU, 2002). The aim of these measures is the restoration of the natural retention function of rivers, on the one hand, and increasing of the catchment area

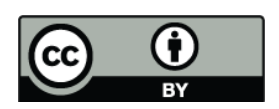

Correspondence to: $\mathrm{W}$. Rieger (wolfgang.rieger@unibw.de) retention capacity one the other. To raise the infiltration ability of soils, land-use changes and various tillage practices such as conservation tillage and reforestation or forest conversion are encouraged. Furthermore, small retention ponds and restoration of rivers as well as unsealing measures in settlements are recommended, but are not considered in this investigation. Due to synergetic effects like groundwater recharge, erosion control or achieving good water status, distributed measures have an enormous advantage compared to central measures. Nevertheless, their effect is debatable due to high space requirements and the need for dry preconditions in a heavy rainfall event to achieve a noticeable effect (Rieger and Disse, 2008).

Tillage practices have a significant effect on runoff generation on arable fields (Zimmerling, 2004). Bare soils are prone to forming soil crusts during extreme rainfall events especially in Loessial soils. Soil crusts promote surface runoff and soil erosion. The crust is characterised by a few millimeters to centimeters thin layer with a low hydraulic conductivity. Mulch tillage leads to a higher amount in soil coverage, thus increasing surface detention and flow resistance. Conservational tillage increases soil stability and the formation of macropores. The use of catch crops allows seasonal soil coverage and therefore diminishes the affinity of soil sealing.

Measures which influence the runoff generation process are especially hard to simulate due to a high degree of uncertainty in soil parameterisation. Modelling results are influenced significantly by the application of different pedotransfer functions (PTF) to estimate soil hydraulic properties (Grundmann, 2009). Furthermore, flood peaks are affected by soil parameterisation, if changed soil physics due to distributed flood control measures (DFCM) are regarded by adopted water-retention curves (Wahren et al., 2009).

Hydrological modelling is often based on pedological maps for the spatial distribution of soil types. According to this information soil type depending hydraulic properties like water-retention curves and saturated hydraulic conductivity are estimated using PTF. As the soil hydraulic properties predominantly effect the runoff generation, adequate parameterisation of soils is one of the most important problems

Published by Copernicus Publications on behalf of the European Geosciences Union. 


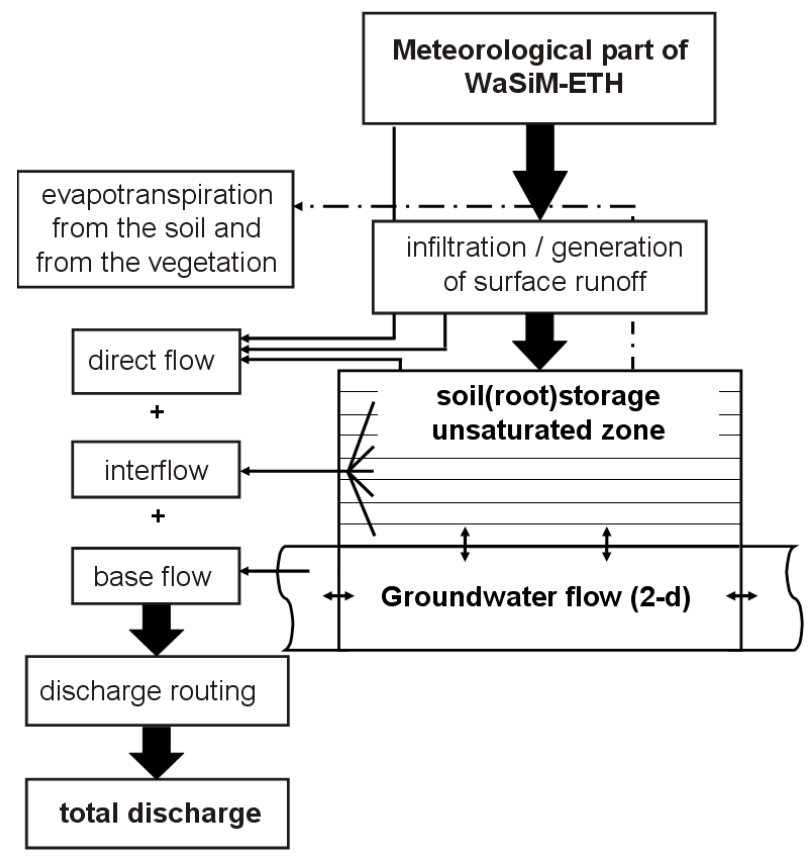

Fig. 1. Flow chart diagram of the WaSiM-ETH model structure.

in physically-based catchment modelling (Rieger and Disse, 2009). Therefore, it is crucial to validate the soil hydraulic properties derived from maps and PTF by field measurements to reduce the uncertainty in simulation results.

The main focus of this paper is how process-orientated modelling of different land-use and tillage practices can be achieved and what kinds of uncertainties in soil parameterisation have to be taken into account.

\section{Material and methods}

The application of a physically based rainfall runoff model is necessary for process-orientated modelling of land-use changes and soil tillage practices (Rieger and Disse, 2009). The model must be able to simulate different types of landuse and vegetation influencing evapotranspiration as well as the water transport in the saturated and unsaturated zone depending on soil type in combination with preferential flow. To be able to make reliable statements about uncertainties in soil parameterisation, it is necessary to use comprehensive experimental datasets of soil measurements. Furthermore, the effects of these uncertainties on modelling results on the catchment scale should be investigated.

\subsection{The hydrological model system WaSiM-ETH 8.4.2}

WaSiM-ETH (Version 8.4.2) is the grid-based Water balance and Simulation Model (Schulla, 1997), which uses predominantly physical and some conceptual approaches (Fig. 1). The multi-layered vegetation with implemented dy- namic phenology determines the potential evapotranspiration according to PENMAN-MONTEITH. Daily parameters for leaf area index (LAI), vegetation covered factor (VCF) and root depth can be defined. The soil model is able to simulate the fluxes within the unsaturated zone according to the RICHARDS-equation by using the description of the water retention curve according to Van Genuchten (1980) and the water content depending unsaturated conductivity according to Mualem (1976) for each soil layer. Furthermore, macropore runoff follows the "bypass-flow-concept" according to Jansson and Karlberg (2001) which describes macropores by three parameters: depth of the macropores, their capacity and the reduction of the capacity per meter soil depth. The real amount of macropore infiltration from bottom to top depends on the actual water content of the adjacent soil layers (Schulla and Jasper, 2007). Drainage discharge can also be generated, which is calculated according to water content of the soil layer around the drainage devices and added to the interflow afterwards. In order to estimate a more realistic groundwater flow, the soil model is coupled in this study with an integrated two-dimensional layered groundwater model. The upper boundary condition for the groundwater model is the vertical flux from the unsaturated zone module. Hereby the groundwater level is located in the lowest unsaturated soil layer. The lateral fluxes are simulated using an implicit finite difference approach whereas the coupling between the groundwater layers is done using leakage factors. The time steps in WaSiM-ETH can be defined between one minute and one day. In this study one hour time step is used.

\subsection{Case study areas}

The modelling area in this study is the northern part of the Windach catchment downstream of a retention basin with a total area of $68 \mathrm{~km}^{2}$. Due to the proximity to the Alps the Windach catchment is characterised by steep slopes and fast responding runoff events. For the same reason precipitation volumes with an amount between $950-1200 \mathrm{~mm} /$ year are mainly caused by orographic events. Grassland is the dominant type of land-use (48\%), followed by coniferous and mixed forest (28\%) and agriculture (17\%) (Fig. 2). The regional geology is characterised by young moraine landscape which was formed during the last ice age. The soils are predominantly silty soils with gravel; luvisols are the main soil types with a medium hydraulic conductivity. In the course of land consolidation and melioration of farmland the Windach tributaries were straightened, whereas the main river is extensively unaffected. Due to the possibility of using part of the grassland as small retention areas, restoring the straightened Windach tributaries and altering tillage practices of the forests and farmland to raise infiltration capacity, the catchment area is suitable for implementing DFCM.

The study area used for soil measurements is the research farm of the former Munich Agricultural Ecosystem Research Community (Forschungsverbund Agrarökosysteme 


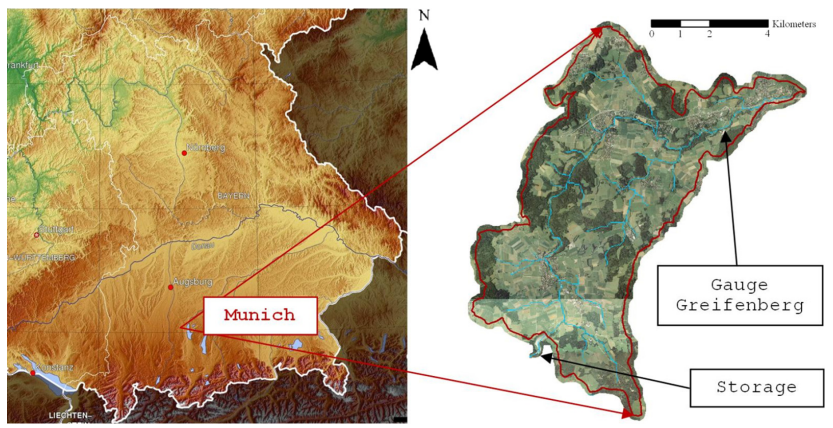

Fig. 2. Location of the northern part of the Windach Catchment with Gauge Greifenberg, retention basin and stream network.

München, FAM), located in Scheyern, about $40 \mathrm{~km}$ north of Munich, Germany. The total area of the farm is $1.6 \mathrm{~km}^{2} \mathrm{com}-$ prising of small catchments on the hillslope scale from 0.8 16.4 ha. Morphologically the area lies within the tertiary hills north of the Alps, and most of the characteristic soil types in central Europe are present in Scheyern with mainly silty loamy soils as in the Windach catchment. The large variation of soil properties results from a wide range of parent materials, the hilly relief and diverse land-use (high-input arable land, pastures, meadows, non-cultivated reed strips beside ponds and creeks, Fig. 3). Because of this heterogeneity, the transfer of the model application to similar catchments with the same morphological characteristics can be ensured (Schröder et al., 2004). Half of the agricultural fields are managed by an integrated conservational tillage practice and optimised crop rotation system, which are within the focus of the investigation area (Auerswald et al., 2001).

\subsection{Model parameterisation and calibration}

In WaSiM-ETH the model parameters are classified in physically-based and conceptual parameters. The latter are primarily to be defined by model calibration and should not be changed anymore after calibration. For a transparent modelling of land-use changes and soil tillage measures, scenarios in WaSiM-ETH are realised by changing the physically based parameters only.

\subsubsection{Parameterisation of current state}

A physically-based parameterisation of hydrological models should be supported by measurements in the investigation area. These data are not prevalent or only partial available so that they have to be substituted by literature values like in this study. The land-use parameters LAI, VCF, root depth, stomata resistance and aerodynamic roughness were taken from references like Hoyningen-Huene (1982), Brutsaert (1982), Burman and Pochop (1994) or Breuer et al. (2003) (see Table 1).

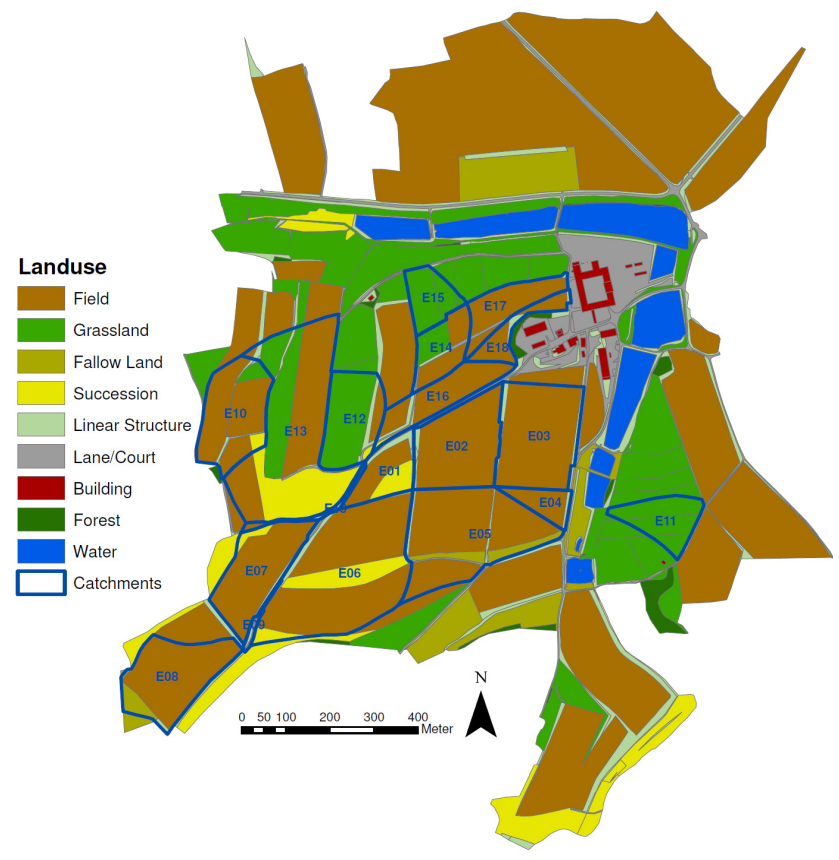

Fig. 3. Land-use and delineation of catchments in the research farm Scheyern.

When the RICHARDS-equation in the soil model of WaSiM-ETH is used, the water tension and unsaturated conductivity is calculated according to the Mualem-VanGenuchten-approach. After the comparison of several PTF (see Sect. 3.1.1) the necessary parameters $\alpha, n, \theta_{\mathrm{s}}$ and $\theta_{\mathrm{r}}$ (saturated and residual water content) as well as $k_{\mathrm{S}}$ (saturated conductivity) were determined by the pedotransfer function according to Carsel and Parrish (1988) and the Bavarian pedological map (Wittmann, 1981). The upper soil layers of forests and grassland contain more organic matter than arable land. The consequences are deeper macropores with increased capacity and a lower bulk density in the upper soils with higher saturated water content as well as higher hydraulic conductivity. This was parameterised in the soil model on the one hand by land-use adapted macropores with e.g. a capacity of $0.8 \mathrm{~mm}$ with a maximum depth of $50 \mathrm{~cm}$ on farmland and a capacity of $2 \mathrm{~mm}$ with a depth of $100 \mathrm{~cm}$ in forests. On the other hand corrections of porosity and saturated conductivity depending on organic content listed in the German guidelines for soil profile description (BGR, 2005) were used. Due to increasing porosity the saturated water content the upper soils rises in grassland by about $20 \%$ and in forests by about $40 \%$, depending on soil type.

Precipitation, wind speed, temperature, global radiation and relative humidity were used as meteorological input. The interpolation method is the inverse distance weighting interpolation combined with altitude dependent regression. Two runoff time series at Gauge Greifenberg with a length of one and two years respectively, including an important flood 
Table 1. Plant parameters used for modeling in WaSiM-ETH.

\begin{tabular}{llllll}
\hline & $\begin{array}{l}\text { LAI } \\
{\left[\mathrm{m}^{2} / \mathrm{m}^{2}\right]}\end{array}$ & $\begin{array}{l}\text { VCF } \\
{[-]}\end{array}$ & $\begin{array}{l}\text { Rooting depth } \\
{[\mathrm{m}]}\end{array}$ & $\begin{array}{l}\text { Stomata resistance } \\
{[\mathrm{s} / \mathrm{m}]}\end{array}$ & $\begin{array}{l}\text { Aerodyn. roughness } \\
{[\mathrm{m}]}\end{array}$ \\
\hline Grassland & $2.0-4.0$ & 1.0 & $0.3-0.6$ & $70-50$ & $0.01-0.08$ \\
Coniferous forest & 9.0 & 0.9 & 0.8 & $80-60$ & 0.15 \\
Mixed forest & $5.0-7.5$ & $0.8-0.9$ & 1.0 & $85-75$ & $0.10-0.15$ \\
Maise & $1.0-4.0$ & $0.2-0.5$ & $0.2-0.5$ & $50-45$ & $0.01-0.10$ \\
\hline
\end{tabular}

Table 2. Calibration and validaton results of WaSiM-ETH 8.4.2 at Gauge Greifenberg $\left(\mathrm{A}_{E}=124 \mathrm{~km}^{2}\right)$, Windach Catchment.

\begin{tabular}{lll}
\hline & Calibration & Validation \\
\hline $\begin{array}{l}\text { Model efficiency } \\
\text { (Nash and Sutcliffe) }\end{array}$ & 0.94 & 0.91 \\
$\begin{array}{l}\text { Volume (simulated)/ } \\
\text { volume (measured) }\end{array}$ & 1.02 & 1.03 \\
Baseflow/total runoff & 0.31 & 0.40 \\
\hline
\end{tabular}

event in each period (recurrence interval of about 10 years), were taken to calibrate (June 2002-May 2003) and validate (June 2003-August 2005) the model. Aside from the optimization of discharge volumes and the model efficiency according to Nash and Sutcliffe (1970) the generation of a realistic relation between the different discharge components was examined. The results of calibration and validation are shown in Table 2.

\subsubsection{Parameterisation of distributed flood control measures}

Conventional soil tillage compared with mulch tillage is used as an example to explain the parameterisation of the distributed flood control measures below. More biological activity and missing plough use result in an increasing amount of macropores and deeper roots. The upper soil, which is more humous, was assigned a higher saturated hydraulic conductivity in contrast to conventional soil tillage with a plough sole, which was parameterised by a lower hydraulic conductivity and almost no macropores and roots beyond. Furthermore, the consideration of bulk densities in the top soil layer is very important, which differ markedly depending on soil tillage and depth (Table 3). Especially the soil crust on the surface and the plough sole are characterised by a high bulk density. The higher organic matter on the first ten centimeters by practicing mulch tillage is characterised by a reduced bulk density. These changes in bulk density are parameterised in the model by a modification of soil hydraulic properties according to BGR (2005).
Table 3. Parameterisation of bulk density for different tillage practices.

\begin{tabular}{llll}
\hline \multirow{2}{*}{ Depth $[\mathrm{cm}]$} & \multicolumn{3}{c}{ Bulk Density $\left[\mathrm{g} / \mathrm{cm}^{3}\right]$} \\
\cline { 2 - 4 } & $\begin{array}{l}\text { Plough Use } \\
\text { without Sealing }\end{array}$ & $\begin{array}{l}\text { Plough Use } \\
\text { with Sealing }\end{array}$ & $\begin{array}{l}\text { Mulch } \\
\text { Tillage }\end{array}$ \\
\hline $0-1$ & 1.35 & 1.75 & 1.20 \\
$1-10$ & 1.35 & 1.35 & 1.20 \\
$10-25$ & 1.35 & 1.35 & 1.50 \\
$25-30$ & 1.60 & 1.60 & 1.55 \\
\hline
\end{tabular}

Other measures were simulated in a similar way, like soil compaction to a depth of $30 \mathrm{~cm}$ by machine usage on farmland or grassland. The parameters to describe the decrease of saturated water content and hydraulic conductivity was obtained according to DVWK (1997) and BGR (2005). Bogs were parameterised also with a fitted retention curve including a high porosity in the top soil decreasing with depth to about $25 \%$ at $30 \mathrm{~cm}$ below surface (Succow and Joosten, 2001). In addition, saturated hydraulic conductivity decreases by 2 orders of magnitude to a depth of $30 \mathrm{~cm}$. A possible ponding of $5 \mathrm{~cm}$ is tolerated. Forest conversion enables higher interception capacity (about 20\%) due to additional vegetation layers for bushes and herbs.

\subsection{Measurements}

Soil hydraulic properties for hydrological modelling in the upper mesoscale (100-1000 $\left.\mathrm{km}^{2}\right)$ like in the Windach catchments are usually taken from the respective maps for soil types like the Bavarian pedological map (Wittmann, 1981). To investigate the accuracy and quality of the spatial distribution of this pedological information, the soil classification according to this map was compared to a comprehensive dataset of soil measurements. This extensive soil sampling campaign was carried out in Scheyern described in Scheinost el al. (1997) which can be used to compare the results in the Windach catchment due to similar soil types. In a rectangular grid of $50 \mathrm{~m}$ resolution, undisturbed soil cores with a total of 471 samples were taken and analysed 
for the main soil properties including grain size distribution, soil texture, $\mathrm{pH}$-value and organic carbon content. The samples were taken both from the topsoil layers and an additional soil layer below the ploughing horizon to account for the differences in vertical soil water transport. In addition 19 reference points have been chosen to represent all subsoil types and tillage practice locations. In total 191 reference samples were taken from the respective horizons and the water retention curves were analysed in the laboratory. From these results a PTF based on the functions according to Vereecken et al. (1989) was developed to estimate the parameters for the van-Genuchten model and the saturated hydraulic conductivity (Scheinost, 1995; Scheinost et al., 1997). The sample set is referred to as the Grid Soil Sampling Campaign in this study.

As the soil samples from the campaign described above were only analysed in the laboratory, additional field measurements were carried out in October and November 2009 on several points in the Scheyern area by a hood infiltrometer to determine the hydraulic conductivity at and near saturation on site. The rate of infiltration in a given soil in relationship with an applied water pressure simulating the water pressure of the soil is enabled by the principle of Mariotte's water supply. The water tension is first equal to zero, simulating an infinite water film on the undisturbed surface, thus measuring infiltration under saturated conditions and determining the saturated hydraulic conductivity directly. The tension is then diminished step by step until reaching the air entry point, which marks the limit of determinable hydraulic conductivity (Schwärzel and Punzel, 2007). Simultaneously, bulk soil samples were taken from the topsoil adjacent to the experiment spot and grain size distribution, soil texture, organic carbon and bulk density were analysed in the laboratory. The results have been taken to apply different PTF (Rawls and Brakensiek, 1982; Carsel and Parrish, 1988; Scheinost et al., 1997) to estimate the parameters of soil hydraulic properties and the saturated hydraulic conductivity.

The locations of the sampling points are shown in Fig. 7.

\section{Results and discussion}

\subsection{Model application}

\subsubsection{Influence of different pedotransfer functions}

For lack of measured data like water tension or soil water content they are often based on assumptions such as the choice of pedotransfer functions (PTF), which generally depend on soil type, grain size distribution, bulk density or organic matter. Their influence on model results is shown in this study by using the following seven functions: Carsel and Parrish (1988), Vereecken et al. (1989), Schaap and Leij (1998), Wösten et al. (1999), Teepe et al. (2003), Zacharias and Wessolek (2007), Weynants et al. (2009).

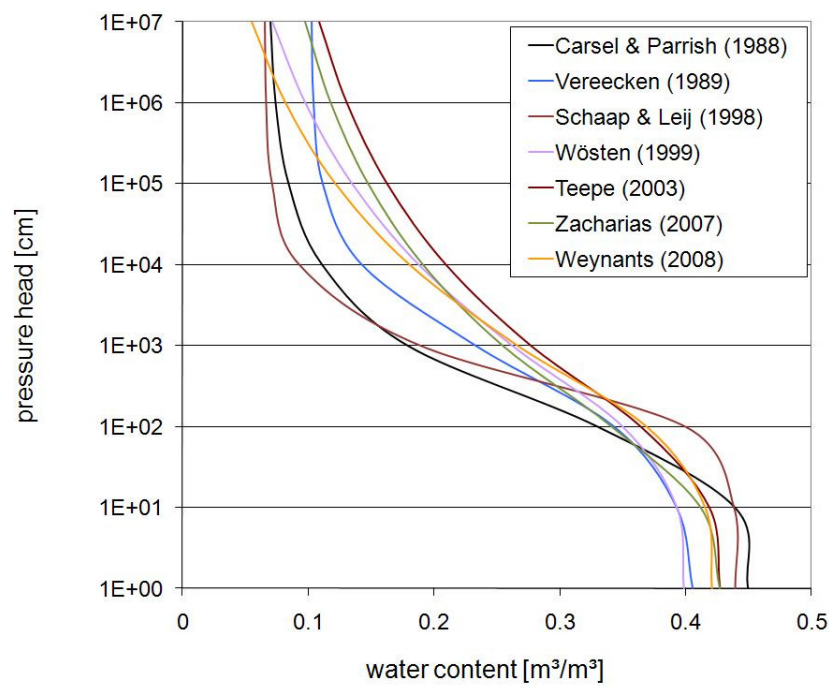

Fig. 4. Different pedotransfer functions (e.g. SIL).

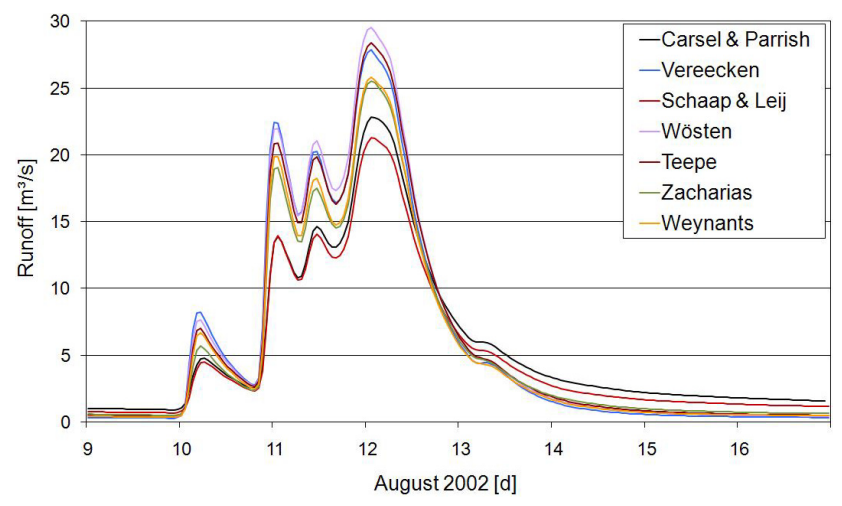

Fig. 5. Windach catchment (northern part, $A_{E}=68 \mathrm{~km}^{2}$ ), $\mathrm{HQ}_{10}$, application of seven different pedotransfer functions.

As an example, luvisols in Fig. 4 show the calculated percolating water varies depending on the chosen PTF between $4 \%$ and $10 \%$ and the available water capacity between $19 \%$ and $34 \%$. The use of different PTF to parameterise the soils in the Windach catchment has a noticeable influence on model results in WaSiM-ETH (Fig. 5).

The modelled hydrographs vary in their peaks by about $30 \%$. Using Wösten and Vereecken, the results show up to $50 \%$ more surface runoff compared to Schaap and Leij and Carsel and Parrish, causing lower groundwater levels by about $70 \mathrm{~cm}$. A non-linear deviation in flood peaks is observed depending on rainfall events: at the first two peaks (10 and 11 August) the Vereecken function generates the highest runoff and the Wösten function at the other (Fig. 5). The reason is the different water content depending on soil hydraulic properties which are defined by the PTF. The Wösten and Vereecken functions result in almost the same saturated water content, but there are e.g. clear differences in the definition of the permanent wilting point (Fig. 4). 

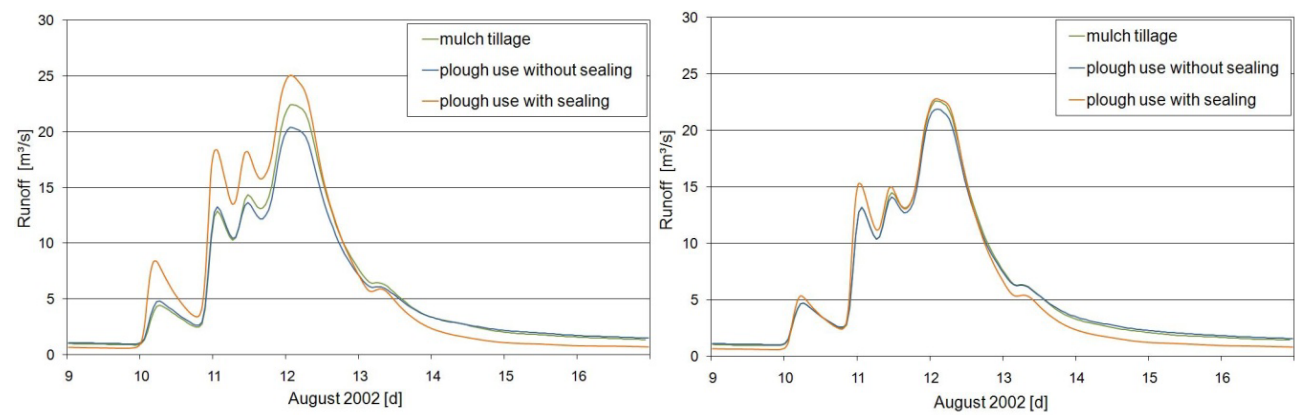

Fig. 6. Windach catchment (northern part, $A_{E}=68 \mathrm{~km}^{2}$ ), $\mathrm{HQ}_{10}$, Land-use scenario: $95 \%$ cropland, left: consideration of bulk density, right: no consideration bulk density.

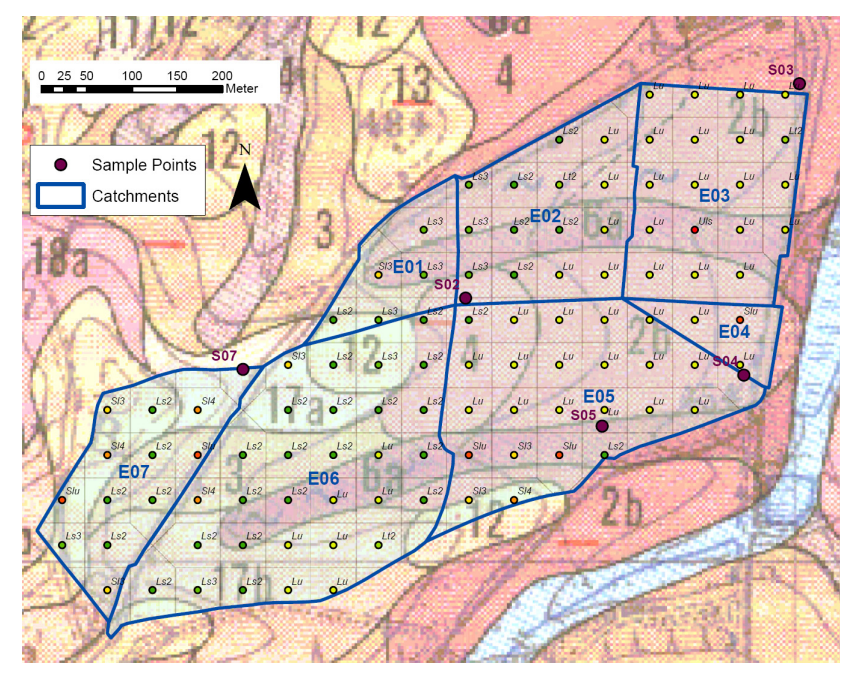

Fig. 7. Location of Hood Infiltrometer Sampling Points and Soil Classification of Topsoil (Scheinost et al., 1997) in Different Catchments, Scheyern (Backgound: Bavarian Soil Map 1:25 000).

\subsubsection{Effectiveness of distributed flood control measures}

The influence of distributed flood control measures to floods was determined by two realistic events with return periods of 10 years (August 2002) and 100 years (May 1999). The flood peak changes of model simulations considering different measures are summarised in Table 4.

The highest peak reduction at both events is enabled by the extreme afforestation scenario with $95 \%$ natural forest. In contrast the realistic afforestation scenario results in a much smaller peak reduction only at the $\mathrm{HQ}_{10}$ event. Forest conversion from coniferous forests to natural mixed forest leads to higher interception capacity with a peak reduction especially at $\mathrm{HQ}_{10}$. Measures on farmland hardly influence the model results with the current state of land-use consisting in $17 \%$ arable land. Therefore, these measures were simulated by an additional land-use scenario with $95 \%$ farmland. They are basically more effective in medium flood events than in rare. Mulch tillage reduces flood events compared
Table 4. Flood Peak Changes in model applications of different distributed flood control measures compared to current state.

\begin{tabular}{|c|c|c|}
\hline \multirow[t]{2}{*}{ Measure } & \multicolumn{2}{|c|}{ Peak change $[\%]$} \\
\hline & $\mathrm{HQ}_{10}$ & $\mathrm{HQ}_{100}$ \\
\hline \multicolumn{3}{|l|}{$\begin{array}{l}\text { Land-use: current state ( } 48 \% \text { grassland, } \\
28 \% \text { forest, } 17 \% \text { farmland) }\end{array}$} \\
\hline Afforestation to $95 \%$ natural forest & -26.2 & -9.9 \\
\hline $\begin{array}{l}\text { Bog restoration (incl. } 5 \mathrm{~cm} \text { ponding. } \\
6 \% \text { bog of catchment area) }\end{array}$ & -5.9 & -2.2 \\
\hline Forest conversion & -5.8 & -0.8 \\
\hline Changing farmland to grassland & -2.7 & -0.4 \\
\hline Afforestation by $10 \%$ (real scenario) & -3.3 & 0 \\
\hline $\begin{array}{l}\text { Mulch tillage compared with } \\
\text { plough use (with sealing) }\end{array}$ & -0.5 & 0 \\
\hline Removal of drainage & -0.3 & 0 \\
\hline Bog restoration (without ponding) & -0.4 & +0.3 \\
\hline Mechanical consolidation on farmland & +0.4 & +0.3 \\
\hline $\begin{array}{l}\text { Mulch tillage compared with plough use } \\
\text { (without sealing) }\end{array}$ & +1.6 & +0.3 \\
\hline Mechanical consolidation on grassland & +1.3 & +0.8 \\
\hline $\begin{array}{l}50 \% \text { - Reduction of drain distance } \\
\text { and drain depth }\end{array}$ & +3.1 & +1.2 \\
\hline $95 \%$ farmland & +12.7 & +3.5 \\
\hline \multicolumn{3}{|l|}{ Land-use: $95 \%$ farmland } \\
\hline $\begin{array}{l}\text { Mulch tillage compared with plough use } \\
\text { (with sealing) }\end{array}$ & -7.6 & -1.1 \\
\hline Mechanical consolidation on farmland & +1.8 & +0.4 \\
\hline $\begin{array}{l}\text { Mulch tillage compared with plough use } \\
\text { (without sealing) }\end{array}$ & +11.6 & +4.1 \\
\hline
\end{tabular}

to plough use only if sealing of surface is regarded (Fig. 6) but it should be preferred compared to plough use, not least because of the synergetic effects of continuous soil coverage. Thus, this measure is primarily effective in catchments with 
Table 5. Soil type according to grain size distribution (German soil classification).

\begin{tabular}{lccc}
\hline Sample & $\begin{array}{c}\text { Bulk } \\
\text { Soil } \\
\text { Sampling }\end{array}$ & $\begin{array}{c}\text { Bavarian } \\
\text { Soil Map } \\
\text { 1:25000 }\end{array}$ & $\begin{array}{c}\text { Grid Soil } \\
\text { Sampling } \\
\text { Campaign }\end{array}$ \\
\hline S02 & Us & Lu & Ls2 \\
S03 & Su3 & Lu & Lu \\
S04 & Us & Lu & Lu \\
S05 & Us & Lu & Lu \\
S07 & S14 & S12 & S13 \\
\hline
\end{tabular}

predominant farmland-use combined with a small or medium flood event. It should be mentioned that in the catchment area drain tiles basically produce more runoff depending on drain distance and drain depth. Bog restoration is only effective if ponding of surface water is enabled.

To show the importance of the consideration of the modified bulk densities in hydrological modelling of DFCM, the influence of different tillage practices is simulated in two ways (consideration of bulk density, no consideration of bulk density). In this case two scenarios with plough use (with/without sealing of the surface) and one scenario with mulch tillage were simulated. Model results are clearly affected by considering the bulk density (Fig. 6) parameterised by a modified saturated water content, which influences the retention curve and unsaturated conductivity of soils. The differences in the flood peaks of the scenarios are increased by a factor of 3 if the effects of modified bulk densities are considered.

\subsection{Field measurement results}

Measurements were taken from five different soils and catchments in the Scheyern area (Fig. 7). Sample locations are labelled according to the respective catchment.

According to grain size distributions, the soil types have been determined from different sources. The bulk samples taken simultaneously to the hood infiltrometer experiments show different results from the Grid Soil Sampling Campaign and the Bavarian Soil Maps (see Table 5). Soils on the lower slopes (S03, S04 and S05) tend to form silt loam colluvial soils with a medium to low hydraulic conductivity. The bulk samples from the lower slopes (S02-S05) underestimate the clay fraction, maybe according to erosion or lessivation of small particle fractions. The bulk sample from the upper slope (S07) overestimates the clay content. A comparison of the Grid Soil Sampling Campaign and the Bavarian Soil Map from is shown in Fig. 7. The sample points S02-S07 are not located on the sample points of the Grid Soil Sampling Campaign. Therefore, the single points are regionalised by Thiessen polygons and labelled by the soil type of the topsoil layer.
Table 6. Saturated hydraulic conductivity $k_{\mathrm{S}}$ according to BGR (2005) and Scheinost et al. (1997).

\begin{tabular}{lcccc}
\hline $\begin{array}{l}\text { Sample } \\
\text { Point }\end{array}$ & $\begin{array}{c}\text { Hood } \\
\text { Infiltrometer }\end{array}$ & $\begin{array}{c}\text { Bavarian } \\
\text { Soil Map } \\
1: 25000\end{array}$ & $\begin{array}{c}\text { Grid Soil } \\
\text { Sampling } \\
\text { Campaign }\end{array}$ \\
\cline { 2 - 5 } & $\begin{array}{c}\text { Field } \\
\text { Measurement }\end{array}$ & Min & Max & $\begin{array}{c}\text { PTF } \\
\text { Scheinost }\end{array}$ \\
& $k_{\mathrm{S}}$ & $k_{\mathrm{S}}$ & $k_{\mathrm{S}}$ & $\begin{array}{c}k_{\mathrm{S}} \\
{[\mathrm{cm} / \mathrm{h}]}\end{array}$ \\
& {$[\mathrm{cm} / \mathrm{h}]$} & {$[\mathrm{cm} / \mathrm{h}]$} & {$[\mathrm{cm} / \mathrm{h}]$} & \\
& 2.60 & 1.67 & 4.18 & 6.54 \\
S02 & 4.07 & 1.67 & 4.18 & 7.40 \\
S03 & 5.38 & 1.67 & 4.18 & 7.25 \\
S04 & 0.71 & 1.67 & 4.18 & 9.08 \\
S05 & 5.82 & 4.18 & 12.49 & 26.62 \\
S07 & & & & \\
\hline
\end{tabular}

Table 7. Saturated hydraulic conductivity $k_{\mathrm{S}}$ from bulk soil sample analysis and application of different PTF.

\begin{tabular}{|c|c|c|c|c|}
\hline \multirow[t]{3}{*}{$\begin{array}{l}\text { Sample } \\
\text { Point }\end{array}$} & $\begin{array}{c}\text { Hood } \\
\text { Infiltrometer }\end{array}$ & \multicolumn{3}{|c|}{$\begin{array}{l}\text { Bulk Soil } \\
\text { Samples }\end{array}$} \\
\hline & $\begin{array}{c}\text { Field } \\
\text { Measurement }\end{array}$ & $\begin{array}{c}\text { PTF } \\
\text { Scheinost }\end{array}$ & $\begin{array}{c}\text { PTF } \\
\text { Carsel- } \\
\text { Parrish }\end{array}$ & $\begin{array}{c}\text { PTF } \\
\text { Rawls- } \\
\text { Brakensiek }\end{array}$ \\
\hline & $\begin{array}{c}k_{\mathrm{S}} \\
{[\mathrm{cm} / \mathrm{h}]}\end{array}$ & $\begin{array}{c}k_{\mathrm{S}} \\
{[\mathrm{cm} / \mathrm{h}]}\end{array}$ & $\begin{array}{c}k_{\mathrm{S}} \\
{[\mathrm{cm} / \mathrm{h}]}\end{array}$ & $\begin{array}{c}k_{\mathrm{S}} \\
{[\mathrm{cm} / \mathrm{h}]}\end{array}$ \\
\hline S02 & 2.60 & 6.47 & 1.04 & 0.14 \\
\hline S03 & 4.07 & 22.83 & 0.45 & 1.19 \\
\hline S04 & 5.38 & 15.98 & 0.45 & 1.34 \\
\hline S05 & 0.71 & 10.00 & 0.45 & 0.28 \\
\hline S07 & 5.82 & 22.83 & 4.42 & 6.66 \\
\hline
\end{tabular}

The results of the hood infiltrometer experiments are shown in Tables 6 and 7 in comparison to the $\mathrm{k}_{\mathrm{s}}$-values derived from other sources. As the experiment is the only way to determine the $\mathrm{k}_{\mathrm{s}}$-values directly in the field, the other results are compared to them. The highest hydraulic conductivity is measured on the sand soil location (S07) and an unexpected low value was detected at S05.

According to the Bavarian Soil Maps the soil types at the sampling locations are cambisols from Loessial top layers and colluvial soils consisting of mainly silty loam at the lower slope prone to form soil crust layers and cambisols from sandy top layers consisting of loamy sand at the upper slope. Estimating the properties from the upper soil layer by using the German guidelines for soil profile description (BGR, 2005), the results represent the minimum and maximum conductivity of the classification following bulk density 
and soil type. The measured values are generally well represented in the theoretical range of the classification. S04 and S05 are not within the range of the theoretical map distribution.

The $\mathrm{k}_{\mathrm{s}}$-values derived from the PTF according to Scheinost (1995) based on the Grid Soil Sampling Campaign generally overestimate the results of the experiments, especially at S05 and S07. Both locations are on the lower slope of their respective catchments and were probably effected by soil translocation due to water and tillage erosion. Generally, Scheinost's approach takes into account the effective porosity $\varphi_{\mathrm{e}}$ as the fraction of the pores that primarily contribute to $k_{\mathrm{s}}$. The effective porosity $\varphi_{\mathrm{e}}$ is defined as the difference of the total porosity of the soil $\varphi$ and the water content at $330 \mathrm{hPa} \theta_{330}$.

Different PTF have been applied to the bulk samples taken simultaneously to the hood infiltrometer experiments (Table 7): Scheinost's PTF greatly overestimated the results of the experiments. Discarding the result of S05, the Scheinost $\mathrm{k}_{\mathrm{s}}$-values are increased by a factor of 4 compared to the hood infiltrometer results. Rawls and Brakensiek's (1982) PTF defined regressions depending on sand and clay content and the total porosity of the soil. The $\mathrm{k}_{\mathrm{s}}$-values tend to be lower than the experimental values, probably due to the underestimation of clay content in the bulk samples. The PTF according to Carsel and Parrish (1988) gives tabular values for the Van Genuchten parameters and $k_{\mathrm{s}}$ for the 12 soil types following the USDA system. The soil textures have been translated to the US soil taxonomy and the values were taken directly from table according to Carsel and Parrish. However, these $\mathrm{k}_{\mathrm{s}}$-values underestimate the measured values by a factor of 2 (Table 7).

For a lower mesoscale model application the parameterisation following the Grid Soil Sampling Campaign seems to be a suitable approach. Different PTF should be applied to diversify a range of feasible values for soil hydraulic properties. Sample experiments are crucial to check the variability of results and support the spatial parameterisation in hydrological modelling.

\section{Conclusions}

Prior to the application of hydrological models, the main goals of the modelling process must be identified and integrated into a sound modelling strategy considering the obtainable data. Physically-based water balance simulation models are able to provide comprehensive possibilities in vegetation and soil parameterisation. However, they require both enormous and reliable data collections and an intensive efforts and care in pre-processing. Often the data for soil parameterisation has to be obtained from literature or available maps in combination with guidelines.

Water balance models (e.g. WaSiM-ETH) often use predominantly physical and some conceptual approaches. Therefore, the physically-based parameters should be iden- tified and defined in a reasonable range prior to calibration. In soil parameterisation, if there is no sufficient data in the investigation area, this could lead to high ranges depending on the respective parameter and scale. The application of soil maps and soil measurements together with different pedotransfer functions (PTF) ensure a feasible range of parameters for the calibration process. Uncertainties in the range of over $10 \%$ in $\theta_{\mathrm{s}}$ and over several orders of magnitude in $k_{\mathrm{s}}$ have to be considered.

The results of this study show that the accuracy and quality of the available pedological information are not entirely conform to actual conditions in the field. Regarding the influence of the soil parameterisation on the modelling results in the upper mesoscale as shown in this study, an even higher influence of incorrect soil assumptions is suspected to affect simulation in the lower mesoscale. Therefore, the heterogeneity of soils at the hillslope scale can hardly be represented especially in mesoscale grid-based model applications, but is to be verified by sample field measurements.

The parameterisation of different tillage practices especially the bulk soil density depending on changing the saturated water content $\theta_{\mathrm{s}}$ and the saturated hydraulic conductivity $k_{\mathrm{S}}$ revealed a high sensitivity in the model application on the catchment scale. However, results must be interpreted in relation to the modelling scale.

The results show that land-use changes and different tillage practices are only effective as distributed flood control measures when the appropriate type of land-use represents a major percentage of the total catchment area. The effects are generally limited to flood events with low return periods. During flood events with soil preconditions close to saturation, the effects of measures adopted mainly to enhance infiltration are of little significance in reducing flood peaks.

Acknowledgements. The authors thank the German Research Foundation (DFG, project DI 639/2-1) and the Bayerisches Landesamt für Umwelt (LfU) for the funding of the actual research and the reviewers for their helpful comments.

Edited by: A. Wahren, F. Tavares Wahren, and K.-H. Feger Reviewed by: M. Wegehenkel and another anonymous referee

\section{References}

Auerswald, K., Kainz, M., Scheinost, A. C., and Sinowski, W.: The Scheyern experimental farm. Research methods the farming system and definition of the framework of site properties and characteristics, in: Ecosystem approaches to landscape management in Central Europe, Springer, Berlin, 2001.

BGR: Bodenkundliche Kartieranleitung der Ad-Hoc-Arbeitsgruppe Boden, in: Herausgegeben von der Bundesanstalt für Geowissenschaften und Rohstoffe, Hannover, 2005 (in German)

Breuer, L., Eckhardt, K., and Frede, H.-G.: Plant parameter values for models in temperate climates, Ecol. Model., 169, 237-293, 2003. 
Brutsaert, W.: Evaporation into the Atmosphere, in: Theory, History and Applications, Reidel, London, 1982.

Burman, B. and Pochop, L. O.: Evaporation, Evapotranspiration and Climatic Data, in: Developments in Atmospheric Science, Vol. 22, Elsevier, Amsterdam, 278 pp., 1994.

Carsel, R. F. and Parrish, R. S.: Developing joint probability distributions of soil water retention characteristics, Water Resour. Res., 24, 755-769, 1988.

DVWK: Gefügestabilität ackerbaulich genutzter Mineralböden, Teil II: Auflastabhängige Veränderung von bodenphysikalischen Kennwerten, Bonn, DVWK-Merkblätter 235, 1997 (in German).

Grundmann, J.: Analyse und Simulation von Unsicherheiten in der flächendifferenzierten Niederschlags-Abluss-Modellierung, Dissertation an der Fakultät Forst-, Geo- und Hydrowissenschaften, TU Dresden, 2009 (in German).

Hoyningen-Huene, J. V.: Die Interzeption des Niederschlages in landwirtschaftlichen Pflanzenbeständen, in: Einfluß der Landnutzung auf den Gebietswasserhaushalt, DVWK Schriften, 57 pp., 1982 (in German).

Jansson, P. E. and Karlberg, L.: Coupled heat and mass transfer model for soil-plant-atmosphere systems, Division of Land and Water Resources, Dept. of Civil and Environmental Engineering, Royal Institute for Technology, Stockholm, TRITA-AMI Report 30, 87 pp., 2001.

Mualem, Y.: A new model for predicting the hydraulic conductivity of unsaturated porous media, Water Resour. Res., 12, 513-522, 1976.

Nash, J. E. and Sutcliffe, J. V.: River flow forecasting through conceptual models. Part I - a discussion of principles, J. Hydrol., 10(3), 282-290, 1970.

Rawls, W. J. and Brakensiek, D. L.: Estimating soil water retention from soil properties, J. Irr. Drain. Eng.-ASCE, 108, 166-171, 1982.

Rieger, W. and Disse, M.: Wasserrückhalt in der Fläche - Möglichkeiten und Grenzen des dezentralen Hochwasserschutzes, Hydrologie und Wasserbewirtschaftung, 52. Jahrgang, Heft 5, 2008 (in German)

Rieger, W. and Disse, M.: Process-orientated simulation of tillage practices and land-use change to optimise distributed flood control measures, European Geosience Union, Wien, 20-24 April 2009.

Schaap, M. G. and Leij, F. J.: Database-related accuracy and uncertainity of pedotransfer functions, Soil Sci., 163, 765-779, 1998.

Scheinost, A. C.: Pedotransfer-Funktionen zum Wasser- und Stoffhaushalt einer Bodenlandschaft, Techn. Univ., Diss., München, Shaker Verlag, Aachen, 1995 (in German).

Scheinost, A. C., Sinowski, W., and Auerswald, K.: Regionalization of soil water retention curves in a highly variable soilscape, 1. Developing a new pedotransfer function, Geoderma, 78(3-4), 129-143, 1997.
Schröder, P., Huber, B., Gerl, G., and Munch, J.: Abschlussbericht der III. Hauptphase 1999-2003, in: Forschungsverbund Agrarökosysteme München: Erfassung, Prognose und Bewertung nutzungsbedingter Veränderungen in Agrarökosystemen und deren Umwelt, GSF Forschungszentrum für Umwelt und Gesundheit, Neuherberg, 2004 (in German).

Schulla, J.: Hydrologische Modellierung von Flussgebieten zur Abschätzung der Folgen von Klimaänderungen, Dissertation am Geographischen Institut der Eidgenössischen Technischen Hochschule Zürich, Züricher Geographische Schriften, Heft 69, 1997 (in German).

Schulla, J. and Jasper, K.: Model description WaSiM-ETH, available at: www.wasim.ch (last access: 02.06.2010), 2007.

Schwärzel, K. and Punzel, J.: Hood infiltrometer - A new type of tension infiltrometer, Soil Sci. Soc. Am. J., 71(5), 1438-1447, 2007.

StMLU: Hochwasserschutz in Bayern, Aktionsprogramm 2020, Bayerisches Staatsministerium für Landesentwicklung und Umweltfragen, München, 2002.

Succow, M. and Joosten, H.: Landschaftsökologische Moorkunde, Schweizerbart, Stuttgart, 2001 (in German).

Teepe, R., Dilling, H., and Beese, F.: Estimating water retention curves of forest soils from soil texture and bulk density, J. Plant Nutr. Soil Sc., 166, 111-119, 2003.

Van Genuchten, M. T.: A Closed-Form Equation for Predicting the Hydraulic Conductivity of Unsaturated Soils, Soil Sci. Soc. Am. J., 44(5), 892-898, 1980.

Vereecken, H., Maes, J., Feyen, J., and Darius, P.: Estimating the soil moisture retention chararacteristic from texture, bulk density and carbon content, Soil Sci., 148, 389-403, 1989.

Wahren, A., Feger, K.-H., Schwärzel, K., and Münch, A.: Land-use effects on flood generation - considering soil hydraulic measurements in modelling, Adv. Geosci., 21, 99-107, doi:10.5194/adgeo-21-99-2009, 2009.

Weynants, M., Vereecken, H., and Javaux, M.: Revisiting Vereecken Pedotransfer Functions: Introducing a Closed-Form Hydraulic Model, Vadose Zone J., 8(1), 86-95, 2009.

Wittmann, O.: Standortkundliche Bodenkarte von Bayern 1:25000 Hallertau, Blatt 7534 Petershausen, Bayerisches Geologisches Landesamt, 1981.

Wösten, J. H. M., Lilly, A., Nemes, A., and Le Bas, C.: Developement and use of a database of hydraulic properties of European soils, Geoderma, 90(3-4), 169-185, 1999.

Zacharias, S. and Wessolek, G.: Excluding Organic Matter Content from Pedotransfer Predictors of Soil Water Retention, Soil Sci., 71(1), 43-50, 2007.

Zimmerling, B.: Beregnungsversuche zum Infiltrationsverhalten von Ackerböden nach Umstellung der konventionellen auf konservierende Bodenbearbeitung, Der Andere Verlag, Osnabrück, 2004 (in German). 